\title{
Successful Treatment of Homozygous Familial Hypercholesterolemia Using Cascade Filtration Plasmapheresis
}

\author{
Homozigot Ailevi Hiperkolesterolemi'nin 'Cascade Filtration' \\ Plazmaferezi ile Başarılı Tedavisi
}

Fatih Kardaş ${ }^{1}$, Aysun Çetin ${ }^{2}$, Musa Solmaz ${ }^{3}$, Rüksan Büyükoğlan ${ }^{3}$, Leylagül Kaynar ${ }^{3}$, Mustafa Kendirci ${ }^{1}$, Bülent Eser ${ }^{3}$, Ali Ünal ${ }^{3}$

${ }^{1}$ Erciyes University, School of Medicine, Department of Pediatric Metabolism, Kayseri, Turkey

${ }^{2}$ Erciyes University, School of Medicine, Department of Biochemistry, Kayseri, Turkey

${ }^{3}$ Erciyes University, School of Medicine, Department of Hematology, Kayseri, Turkey

\section{Abstract}

Objective: The aim of this study was to report the efficacy of low-density lipoprotein cholesterol (LDL-C) apheresis using a cascade filtration system in pediatric patients with homozygous familial hypercholesterolemia (FH), and to clarify the associated adverse effects and difficulties.

Material and Methods: LDL-C apheresis using a cascade filtration system was performed in 3 pediatric patients with homozygous $\mathrm{FH}$; in total, 120 apheresis sessions were performed.

Results: Cascade filtration therapy significantly reduced the mean LDL-C values from $418 \pm 62 \mathrm{mg} / \mathrm{dL}$ to $145 \pm 43 \mathrm{mg} /$ dL $(p=0.011)$. We observed an acute mean reduction in the plasma level of total cholesterol $(57.9 \%)$, LDL-C (70.8\%), and high-density lipoprotein cholesterol (HDL-C) (40.7\%). Treatments were well tolerated. The most frequent clinical adverse effects were hypotension in 3 sessions $(2.5 \%)$, chills $(1.7 \%)$ in 2 sessions, and nausea/vomiting in 3 sessions (2.5\%).

Conclusion: Our experience using the cascade filtration system with 3 patients included good clinical outcomes and laboratory findings, safe usage, and minor adverse effects and technical problems.

Key Words: Familial hypercholesterolemia, Cascade filtration plasmapheresis, Low-density lipoprotein cholesterol (LDL-C)

Özet

Amaç: Çalışmamızın amacı, homozigot ailevi hiperkolesterolemili çocuk hastalarda 'cascade filtration' tekniği ile yapılan düşük dansiteli lipoprotein kolesterol (LDL-C) aferez tedavisinin etkinliğinin tespit edilmesi, işlem sırasında oluşabilecek yan etkilerin ve zorlukların ortaya konulmasıdır.

Gereç ve Yöntemler: Homozigot ailevi hiperkolesterolemili 3 çocuk hastada, 'cascade filtration' sistemi kullanılarak LDL aferezi uygulandı. Tüm hastalar için toplam 120 aferez seansı yapıldı. 
Bulgular: 'Cascade filtration' tedavisi ile ortalama LDL-C seviyeleri, $418 \pm 62 \mathrm{mg} / \mathrm{dl}$ 'den $145 \pm 43 \mathrm{mg} / \mathrm{dl}$ 'ye belirgin olarak düştü $(\mathrm{p}=\mathbf{0 . 0 1 1})$. Total kolesterol, LDL-kolesterol ve HDL-kolesterol'ün plazma seviyelerindeki akut ortalama düşüş sırasıyla, \%57.9, \%70.8, \%40.7 olarak bulundu. Tedaviler iyi tolere edildi. Klinik olarak en sık görülen yan etkiler, 3 seansta hipotansiyon $(\% 2,5), 2$ seansta titreme/üşüme $(\% 1,7)$ ve 3 seansta bulantı/kusma $(\% 2,5)$ idi.

Sonuç: 'Cascade filtration' sistemi ile 3 hastamızın tedavileri sonucunda, yüz güldürücü klinik bulgular ve laboratuvar sonuçlan, güvenli kullanım, yok denecek kadar az yan etki ve teknik problemler tespit edilmiştir.

Anahtar Sözcükler: Ailevi hiperkolesterolemi, 'Cascade filtration' plazmaferez, Düşük dansiteli lipoproteinkolesterol (LDL-C).

\section{Introduction}

Familial hypercholesterolemia (FH) is an autosomal dominant inherited disorder characterized by elevated serum low-density lipoprotein cholesterol (LDL-C). Patients with FH exhibit 2 distinct syndromes, depending on whether the LDL receptor gene is present in the heterozygous or homozygous form. The frequency of the heterozygous form is 1:500 and that of the homozygous form is $1: 1,00,000$ [1]. The most frequent genetic defect is a mutation on the LDL receptor gene, and other rare mutations occur on the ApoB and PCSK9 genes [2]. Clinical manifestations develop earlier in the homozygous form and include tendon xanthomata, arcus cornea, and premature heart disease [1]. Homozygotes develop planar xanthomas on the fingers and toes by the age of 5 years [3]. Coronary heart disease (CHD), and aortic root stenosis develop during adolescence, and myocardial infarction (MI) develop during the third decade. Heterozygotes develop xanthomas during the fourth decade.

Heterozygous patients can be treated effectively with diet and drugs; however, homozygous patients do not respond to these therapeutic interventions [4,5]. In patients with homozygous $\mathrm{FH}$, complications cannot be delayed using these interventions and when they are unsuccessful selective LDL-C apheresis should be considered $[6,7]$. It has been proven that long-term reduction in risk factors can result in regression of coronary stenosis, and in reduced coronary morbidity and mortality [8]. Recent studies indicate that weekly or bi-weekly plasmapheresispreferably LDL apheresis-is the cornerstone of treatment in the majority of children with homozygous FH [9].

Several plasma-apheresis methods have been used in the treatment of homozygous FH, such as Liposorber D, direct adsorption of lipoproteins (DALI), and cascade filtration [10-12]. Membrane differential filtration (MDF) (cascade filtration) is another apheresis technique with which atherogenic lipoproteins can be effectively eliminated from plasma $[4,5]$. With MDF apheresis LDL particles,

lipoprotein(a) [LP(a)], and fibrinogen, which exhibit a large molecular diameter and a high molecular weight, are preferentially retained in the filter and are thus eliminated from the plasma; however, high-density lipoprotein (HDL) particles and other high molecular weight proteins (e.g. immunoglobulins) are also retained, to a certain degree. MDF apheresis, therefore, is a semi-selective LDL apheresis technique [13]. Herein, we present 3 homozygous FH patients treated with LDL apheresis (cascade filtration technique), and a discussion in light of the literature.

\section{Materials and Methods}

\section{Patients}

\section{Patient 1}

A 13-year-old boy admitted to our clinic because his mother was concerned about brown skin lesions on his elbows, knees, and Achilles tendons (Figure la). The primary xanthomas first appeared on his knees and elbows when he was 5 years old. His parents were not consanguineous. His father was diagnosed with $\mathrm{FH}$ and died of MI due to CHD at 25 years of age. His mother's blood lipid

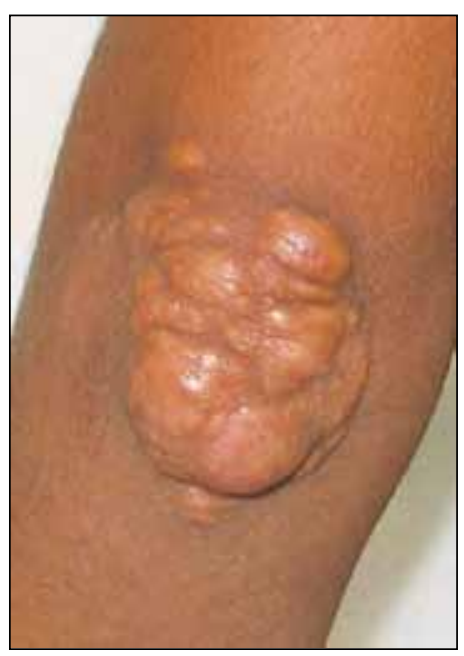

Figure 1A: Pre-apheresis xanthomas on the right elbow of the first patient.

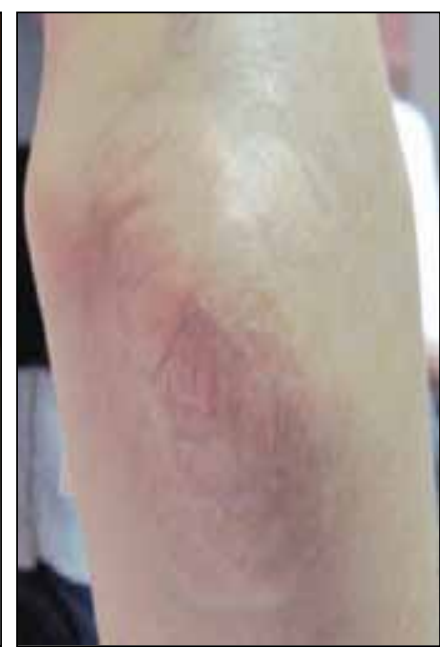

Figure 1B: Post-apheresis xanthomas on the right elbow of the first patient. 
levels were in the normal range. The boy was diagnosed as $\mathrm{FH}$ at another clinic 1 year before presentation and was intermittently treated with atorvastatin $20 \mathrm{mg} \mathrm{d}^{-1}$ for 1 year, but an effective reduction in LDL-C was not achieved.

The patient's growth and developmental history was normal. Physical examination showed multiple brown xanthomas on his elbows, knees, and Achilles tendons. The results of cardiovascular examinations, including echocardiography, were normal. Laboratory investigation results were as follows: total cholesterol: $895 \mathrm{mg} / \mathrm{dL}$; LDLC: $828 \mathrm{mg} / \mathrm{dL}$; HDL cholesterol (HDL-C): $39 \mathrm{mg}$; triglycerides: $140 \mathrm{mg} / \mathrm{dL}$; fibrinogen: $324 \mathrm{mg} / \mathrm{dL}$; immunoglobulin (Ig)G: $702 \mathrm{ng} \mathrm{dL}^{-1}$; IgM: $78 \mathrm{mg} / \mathrm{dL}$; IgA: $118 \mathrm{mg} / \mathrm{dL}$. He was started on a diet low in saturated fat and cholesterol, and a cholesterol-lowering drug combined with cascade filtration apheresis therapy.

\section{Patient 2}

A 15-year-old male patient admitted to our clinic due to yellow skin lesions. The lesions first appeared on his knees when he was 8 years old. He had not been examined or treated prior to presentation. Physical examination showed multiple xanthomas on his knees, elbows, and sacral region. Cardiovascular system examination and echocardiography were normal. Laboratory examination results were as follows: total cholesterol: $731 \mathrm{mg} / \mathrm{dL}$; LDLC: $660 \mathrm{mg} / \mathrm{dL}$; HDL-C: $33 \mathrm{mg} / \mathrm{dL}$; triglycerides: $188 \mathrm{mg} /$ dL; fibrinogen: $281 \mathrm{mg} / \mathrm{dL}$; IgG: 803 mg/dL; IgM: $129 \mathrm{mg} /$ dL; IgA: $124 \mathrm{mg} / \mathrm{dL}$. The patient was clinically diagnosed as homozygous FH. He was started on a diet similar to the previous patient and simvastatin $20 \mathrm{mg} \mathrm{d}^{-1}$, and was followed-up. After 6 months of treatment no regression in blood lipid levels was observed and the clinical features persisted. Apheresis therapy was then added to the therapeutic regimen.

\section{Patient 3}

An 18-year-old male patient (brother of patient 2) presented to our clinic with the same complaints as patient
2. Physical examination showed multiple xanthomas on his knees, elbows, sacral region, and Achilles tendons; the remainder of the examination was normal. Laboratory test results were as follows: total cholesterol: $767 \mathrm{mg} / \mathrm{dL}$; LDLC: $706 \mathrm{mg} / \mathrm{dL}$; HDL-C: $35 \mathrm{mg} / \mathrm{dL}$; fibrinogen: $303 \mathrm{mg} / \mathrm{dL}$; IgG: 787 mg/dL; IgM: 136 mg/dL; IgA: 128 mg/dL. He was clinically diagnosed as homozygous FH. The same conventional treatment given to patient 2 was started and he was followed-up for 6 months. The therapeutic regimen, including diet and cholesterol-lowering therapy, was not effective and LDL apheresis treatment was added to the treatment regimen.

The parents of patients 2 and 3 were consanguineous. The mother's laboratory investigation results were as follows: total cholesterol: $278 \mathrm{mg} / \mathrm{dL}$; LDL-C: $207 \mathrm{mg} / \mathrm{dL}$; HDL-C: $43 \mathrm{mg} / \mathrm{dL}$; triglycerides: $140 \mathrm{mg} / \mathrm{dL}$. The father's results were as follows: total cholesterol: $331 \mathrm{mg} / \mathrm{dL}$; LDLC: $262 \mathrm{mg} / \mathrm{dL}$; HDL-C: $38 \mathrm{mg} / \mathrm{dL}$; triglycerides: $165 \mathrm{mg} /$ dL. The parents' laboratory results showed heterozygous FH. The patients' clinical and biological data at presentation are summarized in Table 1.

\section{Methods}

\section{LDL-C apheresis}

All 3 patients received bi-weekly cascade LDL-C apheresis treatment at the Apheresis Unit of the Hematology Department. The semi-selective apheresis process, developed by Dr. Branger, consists of 2 separation systems. The primary separator device (Fresenius HemoCare, ComTec, Germany) separates plasma from whole blood. A secondary separator device (FC100, Infomed, Geneva, Switzerland) monitors the cascade filter by circulating plasma received from the primary separator and fractionates large proteins, such as LDL-C and fibrinogen (Figure 2). The primary plasma separation was performed using a plasma exchange kit (code: PL1, Fresenius). LDL-C was extracted from plasma product using a tubing set (TU-810-01, Infomed, Geneva, Switzerland) equipped with a fiber cascade filter (membrane surface: $2.0 \mathrm{~m}^{2}$; maximum pres-

Table 1: Family history, and laboratory and clinical features of the patients before LDL apheresis.

\begin{tabular}{c|c|c|c|c|c|c|c} 
Patient & $\begin{array}{c}\text { Age } \\
\text { (years) }\end{array}$ & $\begin{array}{c}\text { LDL-C } \\
(\mathrm{mg} / \mathrm{dL})\end{array}$ & $\begin{array}{c}\mathrm{TC} \\
(\mathrm{mg} / \mathrm{dL})\end{array}$ & $\begin{array}{c}\text { HDL-C } \\
(\mathrm{mg} / \mathrm{dL})\end{array}$ & $\begin{array}{c}\text { TG } \\
(\mathrm{mg} / \mathrm{dL})\end{array}$ & $\begin{array}{c}\text { Xanthomas } \\
\text { history }\end{array}$ \\
\hline $\mathbf{1}$ & 13 & 828 & 895 & 39 & 140 & +++ & + \\
$\mathbf{2}$ & 15 & 660 & 731 & 33 & 188 & +++ & + \\
\hline
\end{tabular}

LDL-C: low-density lipoprotein cholesterol; HDL-C: high-density lipoprotein cholesterol; TC: total cholesterol; TG: triglycerides. 


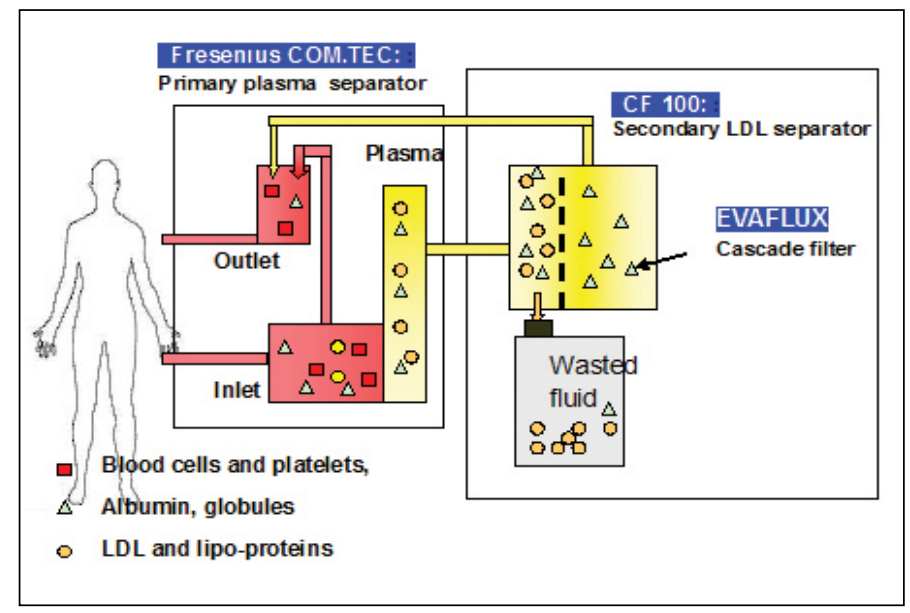

Figure 2: Schematic appearance of cascade filtration system, consisting of two separators.

sure: $66.6 \mathrm{kPa}$ [500 mmHg]) (Evaflux model 5A20, code: 100205, Kawasumi Lab, Inc., Tokyo, Japan).

After attachment of the device via 2 venous access points in the antecubital veins, patient blood was pumped to the plasma filter with a continous flow rate. $(30-50 \mathrm{~mL}$ $\mathrm{min}^{-1}$ ) to the plasma filter. The plasma product was then sent to the plasma bag of the adapter tubing set while controlling the plasma flow rate $\left(15-30 \mathrm{~mL} \mathrm{~min}^{-1}\right)$. Subsequently, the plasma was pumped by a secondary separation device to the hollow fiber cascade filter. High molecular weight proteins and lipoproteins were retained in its hollow fibers. Plasma and proteins with a diameter $<30 \mathrm{~nm}$ passed through the filter and were returned to the replacement bag of the primary set; these were then sent to the patient after being combined with the previously separated whole blood. During apheresis the outlet of the hollow fibers of the cascade filter is closed, but can be opened if the pressure in the filter exceeds $400 \mathrm{mmHg}$, so as to release retinate into a container. After normal saline rinsing of the filter, which is performed automatically, the outlet must be closed again. In the present study the whole blood flow rate was maintained at $30-50 \mathrm{~mL} \mathrm{~min}^{-1}$ and the extracorporeal blood volume was calculated to be $340 \mathrm{~mL}$ (160 $\mathrm{mL}$ in the primary set, $40 \mathrm{~mL}$ in the adapter set, and $140 \mathrm{~mL}$ in the filter). Volume depletion was supported by physiological saline via the primary separator. During these processes the vital functions of all patients were closely monitored.

Before treatment, the primary separator was primed with physiological saline mixed with $1 / 10$ ( $\mathrm{vol} / \mathrm{vol}$ ) of acid citrate dextrose (ACD-A) solution and $25 \mathrm{~mL}$ of $8.4 \%$ sodium bicarbonate solution $\mathrm{L}^{-1}$. The other system was primed with $3 \mathrm{~L}$ of normal saline only. In order to achieve the desired postapheresis LDL-C concentration, processed blood volume requires to be 1.5 fold the calculated plasma volume. During each procedure patient plasma volume was calculated according to the following formula: body weight $(\mathrm{kg}) \times 80 \times\{1-$ [hematocrit (\%) x 0.91] \} (e.g. for a body weight of $35 \mathrm{~kg}$ it should be $35 \mathrm{x} 80 \mathrm{x}$ [ $(1-(0.37 \mathrm{x}$ $0.91)]=1857.24 \mathrm{~mL}$ ) for the adsorption methods.

Lipoprotein analyses, whole blood counts, biochemical parameters, coagulation, and immunoglobulin levels were measured immediately before and after each LDL apheresis session. All laboratory analyses were performed in the Core Laboratory of the Medical Faculty using routine measurements.

\section{Data management, calculation, and statistics}

Acute reduction of lipoproteins after each treatment was calculated from systemic lipoprotein concentrations before and after each apheresis session (LDL- $\mathrm{C}_{\text {pre }}$ and LDL$\mathrm{C}_{\text {post }}$, respectively) using the following equation:

Eq. $1 . \%$ acute reduction of LDL-C $=100\left(\right.$ LDL-C pre $^{-}$LDL$\left.\mathrm{C}_{\text {post }}\right) / \mathrm{LDL}-\mathrm{C}_{\text {pre }}$.

Long-term reductions were calculated based on lipoprotein concentrations at baseline (LDL- $\mathrm{C}_{\mathrm{bl}}$ ), prior to the first treatment session, and the mean inter-apheresis level (LDL- $\mathrm{C}_{\text {mia }}$ ) averaged from the last 3 sessions, as previously described.

Eq. 2. \% long-term reduction of LDL-C $=100\left(\mathrm{LDL}_{\mathrm{bl}} \mathrm{C}_{\mathrm{bl}}-\right.$ LDL-C $\left._{\text {mia }}\right) /$ LDLC $_{b 1}$,

Eq. 3. $\mathrm{LDL}_{\mathrm{mia}}=1 / 4\left(\mathrm{LDL}-\mathrm{C}_{\text {post(n-2) }}+\mathrm{LDL}_{\mathrm{pre}(\mathrm{n}-1)}+\mathrm{LDL}-\right.$ $\mathrm{C}_{\text {post(n-1) }}+$ LDL-C $\left._{\text {pre(n) }}\right)$,

where subscripts (n-2), (n-1), and (n) refer to the antepenultimate, penultimate, and final session, respectively. These formulas were used for all hematological and biochemical parameters (4).

Statistical analysis was performed using SPSS v.15.0 (Chicago, IL, USA). The unit of analysis used here is the apheresis session, not the individual patient. The descriptives provided are averaged over all the three patients. Results are expressed as mean $\pm \mathrm{SD}$. Comparison of differences between pre- and post-treatment values was performed using the paired t test. All the variables were normally distributed which were determined by KolmogorovSmirnov test. A p-value of less than 0.05 was considered to be statisticallly significant.

The local ethics committee approved the study. 


\section{Results}

Patient 1 started LDL apheresis treatment 2 years before this manuscript was written. In total, the patient received 50 sessions of LDL apheresis by cascade infiltration. Mean LDL-C levels before and after treatment were $420 \pm 83 \mathrm{dL}^{-1}$ and $142 \pm 41 \mathrm{mg} / \mathrm{dL}$, respectively. Acute and long-term mean reductions in LDL-C were statistically significant $(\mathrm{p}=0.010, \mathrm{p}=0.023)$. Acute mean reductions in the other parameters were as follows: total cholesterol: 58.2\%; HDL-C: 42.3\%; triglycerides: 57.1\%; fibrinogen: 55.4\%; IgG: 31.4\%; IgM: 18.4\%; IgA: 14.2\%. The xanthomas decreased in size after 1 year, but did not completely disappear.

Patient 2 underwent 35 sessions of LDL apheresis. Mean LDL-C levels before and after treatment were $353 \pm$ $63 \mathrm{dL}^{-1}$ and $136 \pm 34 \mathrm{mg} / \mathrm{dL}$, respectively. Acute and longterm mean reductions in LDL-C were statistically significant $(\mathrm{p}=0.011, \mathrm{p}=0.034)$. Acute mean reductions in the other parameters were as follows: total cholesterol: $61.3 \%$; HDL-C: $40.4 \%$ : triglycerides: $60.9 \%$; fibrinogen: $60.3 \%$; 28. IgG: 6\%; IgM: 16.1\%; IgA: 11.8\%. Regular sessions of LDL apheresis led to resolution of the xanthomas.
Patient 3 also underwent 35 sessions of LDL apheresis. Mean LDL-C levels before and after treatment were $479 \pm$ $64 \mathrm{dL}^{-1}$ and $158 \pm 26 \mathrm{mg} / \mathrm{dL}$, respectively. Acute and longterm mean reductions in LDL-C were statistically significant $(p=0.013, p=0,032)$. Acute mean reductions in the other parameters were as follows: total cholesterol: $54.2 \%$; HDL-C: $39.5 \%$; triglycerides: 59.2\%; fibrinogen: 63.4\%; IgG: $31.4 \%$; IgM: $17.1 \%$; IgA: $10.9 \%$. The majority of the xanthomas disappeared after 20 sessions.

The treatments were well tolerated by all the patients. The most frequently occurring technical problems were related to bloodlines; puncture difficulties (1.7\%) during 2 sessions and insufficient blood flow (13.5\%) during 16 sessions. The main clinical adverse effects were hypotension during 3 sessions (2.5\%), chills (1.7\%) during 2 sessions, and nausea and vomiting during 3 sessions (2.5\%).

Mean session duration was $200 \pm 30$ min and mean blood volume treated ranged from 1,700 to $3,500 \mathrm{~mL}$ session $^{-1}$, depending on the body weight of the patient. Blood flow rate was $35-50 \mathrm{~mL} \mathrm{~min}^{-1}$. In all patients the pre-treatment mean LDL-C value was $418 \pm 62 \mathrm{mg} / \mathrm{dL}$, the post-treatment mean LDL-C value was $145 \pm 43$ ( $\mathrm{p}=$

Table 2: The effects of 120 cascade filtration sessions on hematological, lipid, and biochemical parameters in 3 patients.

\begin{tabular}{|c|c|c|c|c|}
\hline Parameter (unit) & $\begin{array}{l}\text { Pre-apheresis } \\
(\text { mean } \pm \text { SD })\end{array}$ & $\begin{array}{l}\text { Post-apheresis } \\
(\text { mean } \pm \text { SD })\end{array}$ & $\begin{array}{c}\text { Acute Mean } \\
\text { Reduction (\%) }\end{array}$ & p-value \\
\hline Total cholesterol (mg/dL) & $506 \pm 60$ & $241 \pm 38$ & -57.9 & 0.013 \\
\hline LDL-C (mg/dL) & $418 \pm 62$ & $145 \pm 43$ & -70.8 & 0.011 \\
\hline HDL-C (mg/dL) & $49 \pm 7$ & $25 \pm 4$ & -40.7 & 0.014 \\
\hline Triglycerides (mg/dL) & $108 \pm 24$ & $54 \pm 10$ & -59.2 & 0.018 \\
\hline Fibrinogen (mg/dL) & $318 \pm 71$ & $154 \pm 62$ & -59.7 & 0.012 \\
\hline Protein $\left(\mathrm{g} \mathrm{dL}^{-1}\right)$ & $7.3 \pm 1.6$ & $6.6 \pm 1.4$ & -21.5 & 0.037 \\
\hline Albumin $\left(\mathrm{g} \mathrm{dL}^{-1}\right)$ & $4.5 \pm 0.8$ & $4.2 \pm 0.6$ & -14.7 & 0.042 \\
\hline $\operatorname{AST}\left(\mathrm{U} \mathrm{L}^{-1}\right)$ & $1.7 \pm 1.3$ & $16.3 \pm 1.2$ & -5.4 & N.S. \\
\hline $\operatorname{ALT}\left(\mathrm{U} \mathrm{L}^{-1}\right)$ & $22.5 \pm 1.2$ & $22.1 \pm 0.9$ & -1.2 & N.S. \\
\hline $\operatorname{IgG}(\mathrm{mg} / \mathrm{dL})$ & $683 \pm 154$ & $472 \pm 148$ & -30.9 & 0.012 \\
\hline $\operatorname{IgA}(\mathrm{mg} / \mathrm{dL})$ & $134 \pm 41$ & $112 \pm 29$ & -12.3 & 0.024 \\
\hline $\operatorname{IgM}(\mathrm{mg} / \mathrm{dl})$ & $113 \pm 21$ & $104 \pm 16$ & -17.2 & 0.036 \\
\hline $\mathrm{WBC}\left(\mathrm{x} 10^{9} / \mathrm{L}\right)$ & $6.8 \pm 0.7$ & $6.7 \pm 1.2$ & -0.7 & N.S. \\
\hline Platelets $\left(\mathrm{x} 10^{9} / \mathrm{L}\right)$ & $270 \pm 61$ & $248 \pm 47$ & -14.2 & 0.043 \\
\hline $\mathrm{RBC}\left(\mathrm{x} 10^{12} / \mathrm{L}\right)$ & $4.5 \pm 0.6$ & $4.4 \pm 0.4$ & -0.3 & N.S. \\
\hline Hemoglobin $\left(\mathrm{g} \mathrm{dL}^{-1}\right)$ & $13.7 \pm 0.9$ & $13.2 \pm 0.5$ & -5.6 & N.S. \\
\hline $\mathrm{Ca}(\mathrm{mg} / \mathrm{dL})$ & $10.6 \pm 0.8$ & $10.1 \pm 0.4$ & -3.8 & N.S. \\
\hline Glucose (mg/dL) & $98.7 \pm 5.8$ & $96.4 \pm 6.7$ & -1.2 & N.S. \\
\hline
\end{tabular}




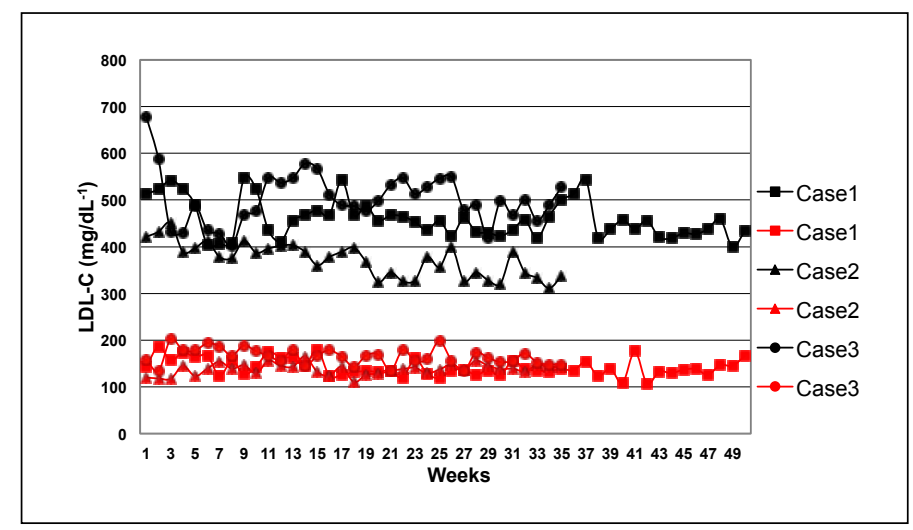

Figure 3: Pre-and post-treatment LDL-C levels

0.011 ), and the acute mean reduction in the LDL-C level was $70.8 \%$. At the end of the treatment sessions LDL-C, HDL-C, total cholesterol, and triglyceride levels returned to normal ranges, and the improvement in lipid profiles was significant (Table 2). Serum protein, albumin, and fibrinogen values decreased significantly after the each treatment session; however, this reduction in the serum protein profile was not clinically important (Table 2). A reduction was observed in immunoglobulin levels, but did not reach abnormal levels (Table 2). The hematological parameters did not change after treatment, except for platelets, but the platelet counts remained within the normal range (Table 2). Pre- and post-treatment LDL-C levels are shown in Figure 3.

\section{Discussion}

Elevated LDL-C causes angina pectoris, MI, and sudden death during the second decade of life in homozygous FH patients. Several studies have shown that long-term LDLapheresis for homozygous FH patients prevents coronary heart disease [1,14]. De Gennes first reported the effectiveness of plasma exchange in successfully reducing plasma cholesterol levels in 1967; it was well tolerated, but repetition of the procedure was emotionally difficult for the patients (15). In 1976 Lupien performed plasmapheresis to selectively remove LDL-C; subsequently, LDL apheresis replaced plasma-exchange therapy [16]. The new procedure was feasible, well tolerated, and had a greater effect on clinical status. Recently, several new apheresis techniques were developed, including dextran sulphatecellulose adsorption (DSA), the heparin extracorporeal LDL precipitation system (HELLP), direct adsorption of lipoprotein using hemoperfusion (DALI), immunoadsorption, and cascade filtration [17-20]. Researchers reported that these technically different procedures were similarly effective in lowering serum LDL-C [21-23].
The American Society for Apheresis (ASFA) recommends cascade filtration plasmapheresis as a standard and acceptable primary treatment modality for FH (category 1) [24]. With the cascade filtration system atherogenic lipoproteins are eliminated from plasma, according to their molecular size. The cascade filter pore diameter is $>15-30$ $\mathrm{nm}$, which ensures that larger plasma proteins (lipoproteins, albumin, fibrinogen, etc.) are caught in the filter, allowing smaller molecules to pass through [25]. In the present study LDL-C levels significantly decreased; mean acute reduction in LDL-C was $70.8 \%$, and reductions in other lipoproteins were as follows: total cholesterol: $57.9 \%$; HDLC: 40.7\%; triglycerides: 59.2\%. The Coker [12] study reported a reduction of $63 \%$ in mean plasma LDL-C using the cascade filtration technique in 10 patients. Zwiener [6] obtained a $71 \%$ reduction in mean plasma LDL-C using the DSA technique in 2 patients. In the Bosh study [4] acute mean reductions in lipoproteins achieved by the DALI system were as follows: LDL-C: $69 \%$; triglycerides: 27\%; HDL-C: 11\%; total cholesterol: 52\%. Another study performed using the cascade filtration system reported the following acute mean reductions: LDL: $61.6 \%$; total cholesterol: 59.5\%; HDL-C: 31.1\%; triglycerides: 48.1\% [26].

Studies have shown that cascade filtration can cause undesirable reductions in other large-molecule proteins, such as immunoglobulins, serum total protein, albumin, and fibrinogen, but these levels remained within normal ranges and were clinically unimportant. In the present study the mean decrease in IgG was 30.9\% and was within the normal range for the patients' age group. Mean decrease in IgG ranged from $27 \%$ to $32 \%$ in other studies $[25,27]$. Although acute mean reductions of $59.7 \%$ in fibrinogen, $21.5 \%$ in serum protein, $14.7 \%$ in serum albumin, and $14.2 \%$ in platelets were noted, we did not observe any infection, hemorrhagia, or edema in our patients. In a study performed using the DALI system acute mean reductions of $15 \%$ in fibrinogen, $6 \%$ in platelets, and $8 \%$ in serum albumin were reported [4]. Another study performed using the cascade filtration system reported mean reductions of $49.9 \%$ in fibrinogen, $19.6 \%$ in albumin, and $26.9 \%$ in serum total protein [26].

Undesirable side effects rarely occur in patients treated with the cascade filtration method. In the REMUKAST study adverse reactions were reported in 34 of 1,702 treatments (2\%), including hypotension (41\%), nausea (18\%), and edema (17\%) [28]. Another study reported the following clinical side effects: hypotension $(0.2 \%)$, chills $(0.1 \%)$, and nausea and vomiting (0.2\%) [12]. We observed similar side effects in the present study (hypotension, chills, 
nausea and vomiting, etc.) and their frequency was not higher than expected.

In conclusion, the cascade filtration technique is a very effective treatment for removing undesirable lipoproteins, such as LDL-C, total cholesterol, and triglycerides, from plasma; it is safe, and is associated with minor adverse effects and negligible technical problems.

\section{Conflict of Interest Statement}

The authors of this paper have no conflicts of interest, including specific financial interests, relationships, and/ or affiliations relevant to the subject matter or materials included.

\section{References}

1. Goldenstein JL, Hobbs HH, Brown MS. Familial hypercholesterolemia. In: Scriver CR, Beaudet AL, Sly WS, Valle D, eds. The Metabolic Basis of Inherited Disease, Vol II, New York: McGraw Hill, 2001;2863-2913.

2. Sun XM, Eden ER, Tosi I, Neuwirth CK, Wile D, Naoumova RP, Soutar AK. Evidence for effect of mutant PCSK9 on apolipoprotein b secretion as the cause of unusually severe dominant hypercholesterolaemia. Hum Mol Genetic 2005;14:1161-1169.

3. Rodriguez-Oquendo A, Kwiterovich PO. Dyslipidemias. In: Fernandes J, van den Berghe G, Walter JH (eds). Inborn Metabolic Disease, Springer Medizin Verlag Heidelberg, 2006; 389-409.

4. Bosh T, Lennertz A, Schenzle D, Drager J. Direct adsorbtion of lipoproteins (DALI) study group Direct adsorbtion of low density lipoprotein and lipoprotein (a) from whole blood: results of the first clinical long-term multicenter study using DALI apheresis. J Clin apheresis 2002;17:161-169.

5. Jensen HK. The molecular genetic basis and diagnosis of familial hypercholesterolemia in Denmark. Dan Med Bull 2002;49:318-345.

6. Zwiener RJ, Uauy R, Petruska ML, Huet BA. Low-density lipoprotein apheresis as long-term treatment for children with homozygous familial hypercholesterolemia. J Pediatr 1995;126:728-35.

7. Makino H, Harada-Shiba M. Long-term effect of low-density lipoprotein apheresis in patients with homozygous familial hypercholesterolemia. Ther Apher Dial 2003;7:397-401.

8. Thompson GR. Progression and regression of coronary artery disease. Curr Opin Lipidol 1992;3:263-267.

9. Kavey RE, Allada V, Daniels SR, Hayman LL, McCrindle BW, Newburger JW, Parekh RS, Steinberger J. Cardiovascular risk reduction in high-risk pediatric patients. A scientific statement from the American Heart Association expert panel on population and prevention science; the councils on cardiovascular disease in the young, epidemiology and prevention nutrition, physical activity and metabolism, high blood pressure research, cardiovascular nursing, and the kidney in heart disease; the Interdisciplinary Working Group on quality of care and outcomes research. Circulation 2006;114:2710-38.

10. Jansen M, Banyai S, Schmaldienst S, Goldammer A, Rohac M, Hoerl W, Derfler K. Direct adsorption of lipoproteins (DALI) from whole blood: first long-term clinical experience with a new LDL-apheresis system for the treatment of familial hypercholesterolaemia. Wien Klin Wochenschr 2000;112:61-69.

11. Otto C, Kern P, Bambauer R, Kallert S, Schwandt P, Parhofer KG. Efficacyand safety of a new whole-blood low-density lipoprotein apheresis system (Liposorber D) in severe hypercholesterolemia. Artif Organs 2003;27:1116-1122.

12. Coker M, Ucar SK, Simsek GD, Darcan S, Bak M, Can S. Low density lipoprotein apheresis in pediatric patients with homozygous hypercholesterolemia. Ther Apher Dial 2009;13:121-128.

13. Matsuda Y, Sueoka A, Nosé Y. An effective LDL removal filter for the treatment of hyperlipidemia. Artif Organs 1995;19:129-134.

14. Al-Shaikh AM, Abdullah MH, Barclay A, Cullen-Dean G, McCrindle BW. Impact of the characteristics of patients and their clinical management on outcomes in children with homozygous familial hypercholesterolemia. Cardiol Young 2002;12:105-112.

15. de Gennes JL, Touraine N, Maunand B, Truffert J, Laudat P. Formes homozygotes cutanéo-tendineuses de xanthomatose hypercholesterolémique dans une observation familiale exemplaire-essai de plasmaphérèse à titre du traitement héroique. Société Médicale du Hôpital de Paris 1967;118:1377.

16. Lupien PJ, Moorjani S, Award J. A new approach to the management of familial hypercholesterolemia: Removal of plasma cholesterol based on the principle of affinity chromatography. Lancet 1976;1:1261-1265.

17. Yokoyama S, Hayashi R, Kikkawa T, Tani N, Takada S, Hatanaka K, Yamamoto A. A Specific sorbent of apolipoprotein B-containing lipoproteins for plasmapheresis. Characterisation and experimental use in hypercholesterolemic rabbits. Arteriosclerosis 1984;4:276282.

18. Eisenhauer T, Armstrong VW, Wieland H, Fuchs S, Scheler F, Seidel D. Selective removal of low density lipoproteins (LDL) by precipitation at low $\mathrm{PH}$; first clinical application of the HELLP system. Klin Woch 1987;65:161-168.

19. Bosch T, Schmidt B, Blumenstein M, Gurland HJ. Lipid apheresis by hemoperfusion: In vitro efficiacy and ex vivo biocompatibility of a new low-density lipoprotein adsorber compatible with human whole blood. Artif Organs 1993;17:640-652. 
20. Richter WO, Jacob BG, Ritter MM, Sühler K, Vierneisel K, Schwandt P. Three-year treatment of familial heterozygous hypercholesterolemia by extracorporeal lowdensity lipoprotein immunoadsorbtion with polyclonal apolipoprotein B antibodies. Metabolism 1993;42:888-894.

21. Thompsom GR. LDL apheresis. Atherosclerosis 2003;167:113.

22. Schwaner I, Von Baeyer H, Bimmermann A, Schwerdtfeger R, Mielenz W. Comparison of various LDL apheresis techniques in terms of protein and lipoprotein handling: Degree of specificity and safety, and cost/efficiency relationship. In: Gotto AM, Mancini M, Richter WO, Schwandt P, eds. Treatment of severe dyslipoproteinemia in the prevention of coronary heart disease. Basel: Karger, 1993:243-252.

23. Parhofer KG, Geiss HC, Schwandt P. Efficacy of different lipoprotein apheresis methods. Ther Apher 2000; 4:382385.

24. McLeod BC. Introduction to the third special issue: clinical applications of therapeutic apheresis. J Clin Apher 2000;15:1-5.
25. Geiss HC, Parhofer KG, Donner MG, Schwandth P. Low density lipoprotein apheresis by membrane differential filtration (cascade filtration). Ther Apher 1999;3:199-202.

26. Barbagallo CM, Averna MR, DiMarco T, Spano L, Scafidi V, Marino G, Camemi AR, Notarbartolo A. Effectiveness of cascade filtration plasmapheresis in two patients affected by familial hypercholesterolemia. J Clin Apher 1995;10:96100.

27. Bambauer R, Olbricht CJ, Schoeppe E. Low-density lipoprotein apheresis for prevention and regression of atherosclerosis: Clinical results. Ther Apher 1997;1:242248.

28. Godehardt E, Messner H, Wallstab UH. Extracorporeal LDL cholesterol elimination by membrane differential filtration. A retrospective analyses of 1,702 treatments. In: Gotto AM, Mancini M, Richter WO, Schwandt P, eds. Treatment of severe dyslipoproteinemia in the prevention of coronary heart disease. Basel: karger, 1993:208-212. 